\title{
Retinoblastoma pM1b TNM Finding v8
}

National Cancer Institute

\section{Source}

National Cancer Institute. Retinoblastoma pM1b TNM Finding v8. NCI Thesaurus. Code C140708.

Retinoblastoma with pathological evidence of tumor in the cerebrospinal fluid or CNS parenchyma. (from AJCC 8th Ed.) 